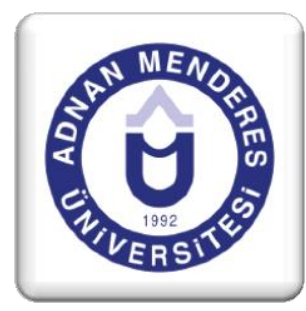

\title{
Başarılı Bir Ortaokulda Okul Müdürünün Çok Faktörlü Liderlik Vasıflarının Araştırılması (Şanlıurfa/Siverek Örneği)
}

\author{
Investigating Multifactor \\ Leadership Characteristics of $A$ \\ Headmaster In A Successful \\ Secondary School \\ (Sanliurfa/Siverek Sample)
}

Yeliz Özkan HIDIROĞLU ${ }^{1}$, Çağlar Naci HIDIROĞLU ${ }^{2}$

\section{Özet}

Çalışmanın amacı, başarılı bir okulun kültüründe okul müdürünün çok faktörlü liderlik stillerinin incelenmesidir. Bu çalışma, başarılı bir okuldaki okul müdürünün liderlik vasıflarının ortaya koyulması açısından tarama çalışmasıdır. Araştırmada öncelikle araştırma kolaylığı dikkate alınmış, sonrasında ise uygun bölgedeki okullar belirlenerek okul seçiminde ölçüt olarak SBS sınavındaki başarı ve öğretmen isteklilikleri önemsenmiştir. Araştırmada, söz konusu ortaokuldaki 24 kadın ve 21 erkek toplamda 45 öğretmen, 1985'te Bernard Bass ve Bruce Avolio tarafından geliştirilen "Çok Faktörlü Liderlik Ölçeği-Lider Formu (MultifactorLeadershipQuestionnaire-MLQ)"nu doldurmuşlar ve araştırmacilar gözlem notu tutmuşlardır. Ulaşılan veriler bilgisayar ortamında sayısallaştırılmış, istatistiksel çözümleme amacıyla SPSS 20 programına girilmiştir. Bu süreçte SPSS 20' de yüzde, aritmetik ortalama ve standart sapma merkezi eğilim ölçülerinden yararlanılmıştır. Araştırma sonucunda, okul müdürünün dönüşümcü liderlik kapsamında kurumun amaç ve hedeflerini tüm personele aktardığı, ahlaki değerlere ve geleneklere saygı gösterdiği; sürdürümcü liderlik kapsamında müdahale gerektiren durumlarda hataları ifade etmekte tereddüt etmediği, dikkatini başarısızlıklar üzerine yoğunlaştırdığı, başarısızlıkta, sürekli gerçekleşen önemli sorunlarda tepki gösterdiği; tam serbestlik tanıyan liderlik kapsamında, ise ihtiyaç duyulduğunda ortada olmadığı ve öğretmenlerin her zaman aynı şekilde işlerini yapmaya devam etmelerinden hoşnut olma eğiliminde olduğu gözlemlenmiştir. Bunun yanında okul müdürünün tek bir liderlik stilindeki davranışları sergilemediği farklı durumlarda farklı liderlik türlerine uygun davranışlarda bulunduğu sonucuna ulaşılmıştır.

Anahtar Kelimeler: Liderlik, okul müdürü, liderlik stilleri.

\footnotetext{
${ }^{1}$ MEB İlköğretim Matematik Öğretmeni

${ }^{2}$ Araş. Gör., Pamukkale Üniversitesi, Eğitim Fakültesi, Eğitim Bilimleri Bölümü
} 


\begin{abstract}
The purpose of the study is to examine multifactor leadership styles of a headmaster in a successful school culture. This study is a survey study because of presenting characteristics of a headmaster in a successful school. In the study, first of all, convenience of study was taken into account and then related schools were decided. While choosing related schools, as a criteria success in SBS (national entrance exam for high schools) exam and teachers' enthusiasm were considered. In the study, 45 teachers (24 female, 21 male) filled out Multifactor Leadership Questionnaire-MLQ which was developed by Bernard Bass and Bruce Avolio in 1985; andthe researchers took observation notes. Data gathered from surveys were digitised and were entered to SPSS 20 programme for statistical analysis. In this process, percentage, arithmetic mean and standard deviation measure of central tendency are used in SPSS 20. As a result, in the scope of transformational leadership; headmaster transfers goals of the institution to all staff and respect for the moral values and tradition. In the scope of transactional leadership, headmaster do not hesitate to express errors in the situations that require intervention, focuses attention on failures, reacts to failures and important matters which constantly occur. In the scope of laissez-faire leadership, headmaster can't be found when needed, have tendency of being happy with the way the teachers continue to do their jobs as they do always. Besides, it is also concluded that headmaster doesn't show behaviours which relate with only one leadership style, she/he shows various behaviours which suit well in other leadership styles in various situations.
\end{abstract}

Keywords: Leadership, headmaster, leadership styles.

\title{
1.Giriş
}

Eğitim sisteminde okullar, toplumun tüm kesimlerinin merkezinde bulunan ve toplumun gelişiminde büyük bir etki alanı oluşturan kültür bütünlügüdür (Alıç, 1991; Hanson, 1985). Okullarda ortaya çıkan örgüt kültürü öğretmeniyle, yöneticisiyle ve öğrencisiyle güçlü bir birlikteliği beraberinde getirmektedir (Demirtaş, 2005). Çünkü toplumun her kesiminde eğitimin oynadığı rol, toplumdaki tüm bireylerin birbirleriyle iletişimlerini etkilerken, davranış tarzlarının oluşmasında da önemli bir etkiye sahip olmaktadır (Şişman, 2004).

Eğitimin yapıtaşı olan okullardaki okul kültürünün yerleşmesinde ve bir ülkedeki eğitim sisteminin rayına oturmasında okul müdürünün rolü çok önemlidir (Bursalıŏglu, 2002; Murphy, 1998). Okul müdürünün liderlik vasıfları yöneticilere, öğretmenlere ve öğrencilere okul kültürünün yerleşmesinde, okulun işlevlerinin tam olarak yerine getirilmesinde ve uzak, genel, özel hedeflerin gerçekleştirilmesinde büyük bir rol üstlenmektedir (Law\&Glover, 2000). Liderliğin, bir grup insanı belirli amaçlar etrafinda toplayabilme, bu amaçları gerçekleştirebilmek için onları harekete geçirecek yetenek ve bilgilerinin toplamı olduğu düşünüldüğünde (Cemaloğlu, 2007); okul müdürlerinin 
okulların işlevlerini yerine getirebilmesinde ve başarılı bir okul kültürünün ortaya çıkabilmesinde sahip olduğu liderlik vasıflarının nitelikleri önem kazanmaktadır.

Tarihin tozlu sayfalarına ve günümüze bakıldığında, örgüt kültürünü içerisinde barındıran tüm topluluklar varlıklarını sürdürebilmede, karşılaştıkları zorlukların üstesinden gelebilmede, topluluktaki insanların çabalarını birleştirmede ve bu çabaları koordine etmede bir lidere ihtiyaç duymuşlardır(Zel, 2001). Bunun yanında, liderler örgütte iletişimin iyi olmasında, ihtiyaçların dikkatle gözlemlenmesinde, gücün yerli yerinde kullanılmasında, grubun güdülenmesinde, desteklenmesinde, güvenin sağlanmasında ve grupta var olan coşkunun ayakta tutulmasında önemli rol oynamaktadır (Sakalli, 2001).

Örgütlerde bu denli önemli olan liderlik kavramına ve anlayış-davranışa göre liderlik sınıflandırmalarına yönelik çalışmaların (Bass, 1985; Burns, 1978; House and Mitchell, 1974; Lewin, Lippitand White, 1939; Reddin, 1970; Vroom and Yetton; 1973) oldukça fazla olduğu görülmektedir. Bu sınıflandırmaların yanında bazı araştırmacılar [örn. Fiedler (1964)] liderlik kavramına yönelik herhangi bir sınıflandırma yapmanın mümkün olmayacağını ve o anki duruma ve şartlarına göre liderlik yöneticilerin liderlik davranışların değişeceğini ifade etmektedir. Yukl(1981), etkili bir liderde olması gereken özellikleri ve beceriler listesini şu şekilde ifade etmektedir (bkz. Tablo 1).

Tablo 1. Yukl'un (1981) Etkili Liderlerle İlişkilendirilen Özellikler ve Beceriler Listesi

\begin{tabular}{ll}
\hline \multicolumn{1}{c}{ ÖZELLIKLER } & \multicolumn{1}{c}{ BECERÍLER } \\
\hline - Duruma uyum sağlayan & - Akıllı ve zeki \\
- Sosyal çevreye dikkate alan & - Kavramsal becerilere sahip \\
- Hırslı ve başarıya dönük & - Yaratıcı \\
- İddialı & - Diplomatik, ince ve nazik \\
- İşbirlikçi & - Akıı ve düzgün konuşan \\
- Kararlı & - Grup görevleri hakkında bilgili \\
- Güvenilir & - Örgütsel yeteneğe (yönetim yeteneğine) sahip \\
- Başkaları üzerinde büyük etki sahibi & - İkna edici \\
- Enerjik & - Sosyal becerilere sahip \\
- Israrcı & \\
- Özgüven sahibi & \\
- Hoşgörülü & \\
- Sorumluluk üstlenen & \\
\hline
\end{tabular}

Liderlik stillerine yönelik çalışmalar incelendiğinde dönüşümcü ve sürdürümcü liderlik stilleri Burns (1978) tarafından alanyazına girmiş ve liderlik araştırmalarına yeni bir bakış getirmiştir. Üzerinde çok durulan ve değişik alanlarda sıkça çalışılan bu liderlik stilleri Bass'ın belirttiği üzere çok boyutlu olup geleneksel liderlik modellerinden daha geniş bir perspektife sahiptir (Burns, 1978 ve Bass, 1985'den aktaran Parkman, 2001).

Burns'e (1978) göre, sürdürümcü liderler geleneklerine ve geçmişine bağlı bir liderlik sergilemektedir. Sürdürümcü liderlikte başarı, liderin ödülü önerme ve sunma yeteneğine bağlıdır. Burns (1978) sürdürümcü liderliğin boyutlarını şu şekilde ifade etmektedir (bkz. Tablo 2). 
Tablo 2. Sürdürümcü Liderliğin Boyutları

\begin{tabular}{|c|c|}
\hline \multicolumn{2}{|r|}{ Sürdürümcü Liderliğin Boyutları } \\
\hline Koşula Bağgl Ödül & $\begin{array}{l}\text { Çabaların karşllı̆̆ verilir, iyi performans ödüllendirilir, başarılar } \\
\text { takdir edilir. }\end{array}$ \\
\hline Beklentiye Göre AktifYönetim & $\begin{array}{l}\text { Ölçüt ve kurallardan sapmalar araştırılıp izlenilir ve kusursuz } \\
\text { eylemde bulunulur. }\end{array}$ \\
\hline Beklentiye Göre Pasif Yönetim & $\begin{array}{l}\text { Ölçütlere karışılmaz ve ölçüt geliştirilmez. Sorun ortaya çıktığı zaman } \\
\text { ilgilenilir. }\end{array}$ \\
\hline Bass (1990) ve & e\&Metcalfe’ nin (2000) çalışmalarından derlenmiştir. \\
\hline
\end{tabular}

Görüldüğü üzere sürdürümcü liderler ödül ve disiplinle koşullu güçlendirme, olumlu aktif ile olumsuz pasif beklentiye göre yönetim davranışı göstermektedir (Metcalfe\&Metcalfe, 2000). Topluluğun sergilediği hizmetlerin karşılığında kaynak ödeneği, görevlendirme ve danışmanlık gibi yarar sağlayıcı eylemlerde bulunmaktadır (Bass\&Steidlmeier, 1999).

Bunun yanında geleceğe, yeniliğe, değişime ve reforma dönük olan dönüşümcü liderlik (Burns, 1978) daha yüksek performansa sahip olma, daha fazla ilerleme gayreti taşıma, çalışanların farkındalıklarını arttırma, çalışanları gelişmeye ikna etme, örgütteki adanma ve inançları ortaya çıkarma şeklinde ifade edilmektedir (Bass, 1985). Dönüşümcü liderliğin temel boyutları Tablo 3' de görülmektedir.

Tablo 3. Dönüşümcü Liderliğin Boyutları

\begin{tabular}{ll}
\hline & \multicolumn{1}{c}{ Dönüşümcü Liderliğin Boyutları } \\
\hline Ilham verici / & Vizyon ve misyon duygusu kazandırır, saygı ve dürüstlüğü vurgular. Hayran olunacak, \\
Karizmatik & güvenilecek davranışlar sergiler, çalışanlar ona benzemeye çalışır. Etrafındakilere ilham \\
Ollhamla & Yü, güdüler, geleceğe iyimser bakar, canlılık ve anlamlılık sağlar. \\
Güdülenme & önemli amaçları açıklar. \\
Entelektüel & Anlayış ve akılcıllğı ilerletir, sorun çözmede dikkatlidir. Soru sormaya, sorunları yeniden \\
Benzeşim & ele alamaya çalışanları cesaretlendirir; eski çözüm yollarına yeni bir bakış getirir, \\
& yaratıcılık ve yenilikleri cesaretlendirir. \\
Bireyselleşmiş & Çalışanlara kişisel dikkat kazandırır, çalışanların her birine rehberlik eder. Çalışanların \\
Etki & potansiyellerini geliştirmeleri ve gelişmeleri için yeni fırsatlar yaratır, her çalışanın istek ve \\
& gereksinimlerini dikkate alır.
\end{tabular}

Bass (1990) ve Metcalfe \& Metcalfe' nin (2000) çalışmalarından derlenmiştir.

Hitt ve Keats'e (1992) göre, dönüşümcü liderlik üç aşamadan meydana gelmektedir. Bunlardan ilki vizyon yaratmadır. İkinci aşamada çalışanların adanması sağlanmaya çalışılır. Üçüncü aşama ise değişimin kurumsallaşmasını kapsamaktadır. Burns' un (1978) bu dönüşümcü ve sürdürümcü liderlik ayrımı, Kurt Lewin'in otokratik, demokratik, tam serbesti tanıyan ayrımına karşı geliştirilmiştir (Eren 2004). Daha sonra Bass (1990) tarafından bu liderlik modeli geliştirilerek liderlik türleri dönüşümcü, sürdürümcü ve tam serbestlik tanıyan liderlik olmak üzere üç boyutta ele alınmıştır.

Serbestlik tanıyan liderlikte, liderler dönüşümcü ve sürdürümcü liderlikte bahsedilen davranışları göstermekten kaçınırlar (Bass\&Steidlmeier 1999). Serbestlik tanıyan liderlik, daha çok sürdürümcü liderliğin müdahale etmeme boyutunda ele alınmaktadır (Özer, 2009). Başka bir ifadeyle, serbestlik tanıyan liderler yetkiye sahip çıkmamakta ve yetki kullanma haklarını tamamıyla astlara bırakmaktadırlar (Eren 2004). Kültür düzeyi düşük, iyi bir işbölümüne sahip olmayan ve sorumluluk 
duygusundan yoksun bulunan gruplarda bu tarz bir liderlik biçiminin yürümeyeceği bellidir (Ayhan 2006). Çünkü serbestlik tanıyan liderlik tarzı liderin otorite kullanmasını adeta ortadan kaldırmaktadır.

Liderlik kavramına yönelik çalışmalara bakıldığında, Bass'ın (1990) veBurns (1978)'ün yardımıyla geliştirdiği sınıflandırmanın çalışmalarda dikkate alındığı ve bu sınıflandırmayı göz önünde bulundurarak birçok çalışmanın gerçekleştirildiği görülmektedir. Bu doğrultuda, çalışmada başarılı okul kültüründeki okul müdürünün liderlik vasıflarının açıklanmasında Bass'ın (1990) liderlik sınıflandırması temel alınmıştır.

Bununla birlikte ülkemizin ihtiyacı olan insan gücünü yetiştirme sorumluluğunu üstlenen, eğitim ve ögretimin temel taşlarından olan okulların daha etkin hale gelebilmeleri amacıyla başarılı bir okul kültüründeki okul müdürünün nasıl bir örgütsel liderlik sergilemesi gerektiğinin açıklanması önemli olmaktadır. Bu yüzden, başarılı bir okuldaki okul müdürünün nasıl bir liderlik sergilemesi gerektiğinin açıklanması önemlidir. Bu doğrultuda çalışmanın amac1, başarılı bir okul kültüründeki okul müdürünün çok-faktörlü liderlik vasıflarının betimlenmesidir.

$\mathrm{Bu}$ bağlamda, çalışma sonunda elde edilen veriler 1şığında ülkenin ihtiyacı olan insan gücünü yetiştirme sorumluluğunu üstlenen, eğitim ve öğretimin temel taşlarından olan öğretmenlerin çalıştıkları ortamda huzurlu olmaları, eğitim görevlerini severek ve isteyerek yerine getirmeleri ve daha etkin kılınabilmeleri amacıyla örgütsel vatandaşlık davranışı göstermelerini etkileyen okul müdürlerinin nasıl bir lider davranış biçimi sergilemeleri gerektiği konusunda çeşitli öneriler geliştirilmiştir.

\section{Gereç ve Yöntem}

\subsection{Araştırmanın Modeli}

Nicel araştırma türlerinden betimsel nitelikte olan bu çalışmada tarama modellerinden genel tarama modeli kullanılmıştır. Genel tarama modelleri, çok sayıda elemandan oluşan bir evrende, evren hakkında genel bir yargıya varmak amacı ile evrenden alınacak bir grup, örnek ya da örneklem üzerinde yapılan tarama düzenlemeleridir (Karasar, 2004). Çalışmada, evrenden seçilen örneklemdeki bireylerden tek seferde verilerin toplanması esasına dayalı olarak tekil tarama desenlerinden biri olan anlık tarama deseninden yararlanılmıştır (Büyüköztürk, KılıçÇakmak, Akgün, KaradenizveDemirel, 2013).

\section{2. Örneklem}

Çalışma, başarılı bir ortaokulda görev yapan 45 (kırk beş)öğretmen ile gerçekleştirilmiştir. Araştırma grubunun yer aldığı okul seçilirken çalışmanın amacını yansıtması açısından amaçlı örnekleme yöntemlerinden ölçüt örnekleme yöntemi kullanılmıştır. Bu örnekleme yönteminde temel anlayış önceden belirlenmiş bir dizi ölçütü karşılayan durumların dikkate alınmasıdır (Yıldırım ve Şimşek, 2011). Ölçüt örnekleme yöntemine göre Şanlıurfa/Siverek ilçesindeki 2013 yılında SBS'de en başarılı olmuş ortaokulda çalışma yürütülmüştür. Ayrıca bu okuldaki öğretmenlerin isteklilikleri de ölçüt olarak göz önünde bulundurulmuştur.

\subsection{Veri Toplama Araçları}

Başarılı bir okul kültüründeki okul müdürlerinin liderlik davranışlarını gösterme düzeylerini belirlemek amacıyla "Çoklu Faktör Liderlik Ölçeği-Lider Formu" (Bass ve Avolio, 1985) ölçeği kullanılmıştır. Çok sayıda çalışmada bu ölçek kullanılarak, yüksek geçerliliğe sahip olduğu ortaya konulmuştur (Ramey, 2002; Stumpf, 2003; Dilek, 2005; Ayhan, 2006; Kılıç, 2006). Çoklu Faktör Liderlik Ölçeği-Lider Formu ölçeği, Türkiye'deki koşullar ve Türk Eğitim Sisteminin yapısı ile ilgili 
bazı faktörler dikkate alınarak yeniden düzenlendiği Özer(2009)'in çalışmasındaki haliyle bu çalışmada ele alınmıştır. Liderlik davranış biçimleri ile ilgili ölçeğin güvenirliği 0,94 olarak tespit edilmiştir (Özer, 2009).

Liderlik ile ilgili tasarlanan ölçekte öğretmenlerden şimdiki okul müdürlerinin belirtilen davranışları ne sıklıkla gösterdiklerini işaretlemeleri istenmiş ve bunun için 5'li Likert ölçeği kullanılmıştır $(1=$ Hiçbir Zaman; 2 = Nadiren; 3 = Arada Sırada; 4 = Sık S1k; 5 = Her Zaman). Veri toplama aracının ön uygulaması örneklem dışından 4 öğretmene uygulanarak yapılmıştır ve anlamakta güçlük çekilen ifadelerin düzenlenmesi için öğretmen ve uzman görüşleri alınmıştır. Düzenlemeler sadece bazı kelimelerin değiştirilmesi ve daha uygun kelimenin kullanılması şeklinde olmuştur. (Örneğin yönetici yerine okul müdürü, işyeri yerine okul,..gibi) Ayrıntılı bir incelemeyi sağlamak amacıyla, yapılandırılmamış gözlem formu anlayışı (Büyüköztürk, Ş., Kılıç Çakmak, E., Akgün, Ö.E., Karadeniz, Ş. ve Demirel, F.,2013)dikkate alınarak araştırmacıların okuldaki gözlem notlarından faydalanılmıştır.

\subsection{Veri Toplama Süreci}

Veri toplama aracı olarak hazırlanan ölçek formunun uygulanabilmesi için 2013-2014 Eğitim-Öğretim Y1lı güz döneminde Şanlıurfa'nın Siverek ilçesindeki en başarılı ortaokulda görev yapan ögretmenlerin tamamına 53 adet ölçek formu dağıtılmıştır. Toplam 47 ölçek formu geri dönmüş, bunlar arasından bilimsel açıdan kullanılabilir nitelikte olduğu düşünülen toplam 45 ölçek formu elde edilmiştir. Dolayısıyla, ölçeklerin geri dönüş oranı \% 84,9 olarak gerçekleşmiştir. Bu oran, bilimsel yeterlilik açısından kabul edilebilir düzeydedir (Kılıç, 2006).

Araştırmacılar okulda bulundukları süre içerisinde araştırmanın amacını yansıtacak gözlem notlarını oluşturmuşlardır. $\mathrm{Bu}$ doğrultuda okulun işleyişi, öğretmen-öğrenci-müdür ilişkisi, müdürün kişisel özellikleri, mesleğine ve okulun hedeflerine yönelik bakış açısı, okula yönelik projeleri vb. durumlar informal görüşmelerin de ışığında gözlem notlarına yansıtılmıştır.

\subsection{Verilerin Analizi}

45 öğretmene uygulanan ölçek sonucunda ulaşılan veriler bilgisayar ortamında sayısallaştırılmış, istatistiksel çözümleme amacıyla SPSS 20 programına girilmiştir. Bu süreçte öğretmenlerin okul müdürünün çok faktörlü liderlik davranış biçimleri ile ilgili algılarını ortaya koymak için yüzde, aritmetik ortalama ve standart sapma merkezi eğilim ölçülerinden yararlanılmıştır. Araştırmada ölçeğin güvenirliği .923 olarak bulunmuştur. Bunun yanında, dönüşümcü liderlik boyutunun güvenirliği .956; Sürdürümcü liderlik boyutunun güvenirliği .842; tam serbestlik tanıyan liderlik boyutunun güvenirliği .829 olarak bulunmuştur.

Araştırmacıların gözlem notlarının analizinde betimsel analizden (Büyüköztürk, Ş., Kılıç Çakmak, E., Akgün, Ö.E., Karadeniz, Ş. ve Demirel, F., 2013) yararlanılmıştır. Bu sayede çalışmanın geçerliliği ve güvenilirliği artırılmaya çalışılmıştır.

\section{Bulgular}

Bu bölümde öğretmenlerin okul müdürlerinin çok faktörlü liderlik davranış biçimleri (sürdürümcü, dönüşümcü ve tam serbestlik tanıyan liderlik) ile ilgili algılarına ilişkin bulgular ve yorumlar yer almaktadır. Öğretmenlerin görüşleri dikkate alındığında, okul müdürünün hangi liderlik vasıflarını daha çok taşıdığına ilişkin ortalama ve standart sapma verilerini içeren bilgilerTablo 4'de verilmektedir. 
Tablo 4. Öğretmenlerin Okul Müdürlerinin Çok Faktörlü Liderlik Davranış Biçimlerini Algılamalarına Yönelik Genel Bulgular

\begin{tabular}{cccc}
\hline & Dönüşümcü Liderlik & Sürdürümcü Liderlik & $\begin{array}{c}\text { Tam Serbestlik Tanıyan } \\
\text { Liderlik }\end{array}$ \\
\hline $\bar{X}$ & 2.38 & 2.81 & 2.79 \\
$\mathbf{S}$ & 1.22 & 1.25 & 1.39 \\
\hline
\end{tabular}

Tablo 4'e göre, öğretmenlerin okul müdürlerinin sürdürümcü ve tam serbestlik tanıyan liderliklere daha yakın özellikler taşıdığı görülmektedir. Bunun yanında, okul müdürünün dönüşümcü liderlik davranışlarını da taşıdığı anlaşılmaktadır. Her liderlik stili dikkate alındığında öğretmenlere göre okul müdürünün çok faktörlü liderlik puanı her bir kategori için de orta seviyede sayılabilecek bir konuma sahiptir. Ayrıca, dönüşümcü ve sürdürümcü liderlik stilinde öğretmen algılarının yaklaşık 1.22 standart sapmayla tam serbestlik tanıyan liderlikteki algılarından (1.39)daha homojen olduğu görülmektedir. Tabloya göre, öğretmenler, genel olarak okul müdürlerinin her liderlik stiline uygun bazı davranışlara sahip olduğunu ifade etmişlerdir. Öğretmenler okul müdürlerinin liderlik özelliklerini açıklarken ölçekteki maddelerin aritmetik ortalaması 1.87 ve 3.49 arasında değiştiği görülmüştür.

Araştırmanın birinci alt amac1; başarılı bir ortaokulda görev yapmakta olan okul müdürünün dönüşümcü liderlik vasıflarının neler olduğunu ortaya koymaktır. $\mathrm{Bu}$ amaca ilişkin sonuçlar Tablo5'de verilmiştir.

Araştırma verilerine göre, okul müdürünün okul kültürü içerisinde en çok gösterdiği dönüşümcü liderlik davranışları, ahlaki değerlere ve geleneklere saygı göstermesi (\% 75.5) ve kurumun amaç ve hedeflerini tüm personele aktarması (\% 66.7) olarak belirlenmiştir. Bu doğrultuda, okul müdürünün okul kültüründeki her bir bileşene ayrı ayrı gerekli değeri verdiği ve kurum bilinci içerisinde okul kültürünü oluşturmaya çalıştığı göze çarpmaktadır. Gözlem notlarından da müdürün okul kültürüne ve bütünlüğüne önem verdiği görülmüştür.

"Müdür, sınavda beklenmeyen başarısızlığın sonrasında yaptığı toplantıda kurumun amaç ve hedeflerini ortaya koydu ve öğretmenlerden bu yönde bir çaba beklediğini vurguladı... Rehber öğretmenlerden biri bu tür toplantıların her ay gerçekleştiğini, müdürün öğrenci başarıları ve okulun sorunları hakkında öğretmenlerin görüşlerini aldığını söyledi." (Gözlemci Notu: Gözlemci A)

Bunun yanında, okul müdürünün öne çıkan olumlu özelliklerinin ise; sorunların çözümünde farklı yaklaşımlar araması(\% 57.8), tüm çalışanlara kendine has kişiliği olan bir birey gibi davranması (\% 57.8) ve yaratıcı ve yenilikçi düşünceye sahip personeli desteklemesi (\% 55.5) olduğu görülmektedir. $\mathrm{Bu}$ durum, okul müdürünün okuldaki yaratıcı ve farklı yaklaşımları dikkate alan, okul kültüründe değişime açık ve farklı1ıklara değer veren bir lider rolü üstlendiğini göstermektedir. Gözlem notlarına bakıldığında, okul müdürünün toplantılarda öğretmenlerin beklenti ve düşüncelerini dinlediği, onlar için daha iyi bir çalışma ortamı hazırlamaya çalıştığı görülmüştür. 
Tablo5. Öğretmenlerin Görüşlerine Göre Okul Müdürünün Dönüşümcü Lider Davranışlarını Algılamalarına Yönelik Bulgular

\begin{tabular}{|c|c|c|c|c|c|c|c|c|c|}
\hline & A. Dönüşümcü Liderlik & $\frac{\text { bos }}{\text { c }}$ & $\frac{1}{c}$ & $\underline{\mathbf{2}}$ & $\underline{\mathbf{3}}$ & $\frac{4}{\%}$ & $\underline{5}$ & $\bar{X}$ & $\mathbf{S}$ \\
\hline $\mathbf{1}$ & Okul müdürüyle çalışmak bana gurur veriyor. & 0 & 28.9 & 33.3 & 26.7 & 6.7 & 4.4 & 2.24 & 1.090 \\
\hline 2 & $\begin{array}{l}\text { Okul müdürü çalışanların ihtiyaç ve } \\
\text { beklentilerini düşünür. }\end{array}$ & 0 & 17.8 & 22.2 & 20.0 & 15.6 & 4.4 & 2.67 & 1.087 \\
\hline 3 & $\begin{array}{l}\text { Okul müdürü yetkili olduğunu hissettirir, güven } \\
\text { verir ve saygıyı hak ediyor. }\end{array}$ & 2.2 & 20.0 & 17.8 & 28.9 & 24.4 & 6.7 & 2.73 & 1.286 \\
\hline 4 & $\begin{array}{l}\text { Okul müdürü, okulun amaçlarına ulaşılmasında } \\
\text { davranışlarıyla örnek olmaktadır. }\end{array}$ & 2.2 & 22.2 & 26.7 & 31.1 & 15.6 & 2.2 & 2.42 & 1.138 \\
\hline 5 & $\begin{array}{l}\text { Okul müdürü kurumun amaç ve hedeflerini tüm } \\
\text { personele aktarır. }\end{array}$ & 0 & 11.1 & 22.2 & $\underline{22.2}$ & $\underline{28.9}$ & $\underline{15.6}$ & $\underline{3.16}$ & 1.261 \\
\hline 6 & $\begin{array}{l}\text { Okul müdürünün yakınında kendimi iyi } \\
\text { hissederim ve müdür ilham kaynağımdır. }\end{array}$ & 0 & $\underline{51.1}$ & $\underline{26.7}$ & 8.9 & 11.1 & 2.2 & $\underline{1.87}$ & 1.120 \\
\hline 7 & $\begin{array}{l}\text { Okul müdürü, görüşlerini açıkça belirtmeleri için } \\
\text { personeli cesaretlendirir. }\end{array}$ & 0 & 24.4 & 37.8 & 11.1 & 20.0 & 6.7 & 2.47 & 1.254 \\
\hline 8 & $\begin{array}{l}\text { Okul müdürünün, benim açımdan düşünülmesi } \\
\text { gereken önemli noktanın ne olduğunu görmekte } \\
\text { özel bir yeteneği vardır. }\end{array}$ & 0 & $\underline{44.4}$ & $\underline{24.4}$ & $\underline{15.6}$ & 6.7 & 8.9 & $\underline{2.11}$ & 1.301 \\
\hline 9 & $\begin{array}{l}\text { Okul müdürü iyimser ve coşkulu bir tavırla } \\
\text { konuşarak, geleceğe dönük iyimserliği arttırır. }\end{array}$ & 0 & 28.9 & 33.3 & 20.0 & 8.9 & 8.9 & 2.36 & 1.246 \\
\hline 10 & $\begin{array}{l}\text { Okul müdürü beraber çalıştığı insanlarda, neleri } \\
\text { başarabileceklerine dair görüşleriyle heyecan } \\
\text { uyandırır. }\end{array}$ & 2.2 & $\underline{31.1}$ & $\underline{35.6}$ & $\underline{20.0}$ & 6.7 & 4.4 & $\underline{2.11}$ & 1.133 \\
\hline 11 & $\begin{array}{l}\text { Okul müdürü ahlaki değerlere ve geleneklere } \\
\text { sayg1 gösterir. }\end{array}$ & 0 & 6.7 & 17.8 & $\underline{20.0}$ & $\underline{31.1}$ & $\underline{24.4}$ & $\underline{3.49}$ & 1.236 \\
\hline 12 & $\begin{array}{l}\text { Okul müdürü yaratıcı ve yenilikçi düşünceye } \\
\text { sahip personeli desteklemektedir. }\end{array}$ & 0 & 20.0 & 24.4 & $\underline{22.2}$ & $\underline{13.3}$ & $\underline{20.0}$ & $\underline{2.89}$ & 1.418 \\
\hline 13 & $\begin{array}{l}\text { Okul müdürü sorunların çözümünde farklı } \\
\text { yaklaşımlar arar. }\end{array}$ & 0 & 15.6 & 26.7 & $\underline{28.9}$ & $\underline{20.0}$ & $\underline{8.9}$ & $\underline{2.80}$ & 1.198 \\
\hline 14 & $\begin{array}{l}\text { Okul müdürü görevlerin nasıl tamamlanacağına } \\
\text { yönelik yeni bakış açıları önerir. }\end{array}$ & 2.2 & 17.8 & 35.6 & 20.0 & 20.0 & 4.4 & 2.51 & 1.199 \\
\hline 15 & $\begin{array}{l}\text { Okul müdürünün fikirleri, beni, daha önce } \\
\text { sorgulamadı̆gm fikirlerimi yeniden düşünmeye } \\
\text { zorlar. }\end{array}$ & 0 & 28.9 & 31.1 & 33.3 & 4.4 & 2.2 & 2.20 & .991 \\
\hline 16 & $\begin{array}{l}\text { Okul müdürü eğer mecbur kalırsak onsuz da } \\
\text { hedeflere ulaşabileceğimizi bize hissettirir. }\end{array}$ & 4.4 & 31.1 & 15.6 & 17.8 & 11.1 & 20.0 & 2.60 & 1.615 \\
\hline 17 & $\begin{array}{l}\text { Okul müdürü ihmal edilmiş gözüken personele } \\
\text { kişisel dikkatini verir. }\end{array}$ & 0 & $\underline{35.6}$ & 26.7 & $\underline{33.3}$ & 2.2 & 2.2 & $\underline{2.09}$ & .996 \\
\hline 18 & $\begin{array}{l}\text { Okul müdürü ne istediğimi keşfeder ve elde } \\
\text { etmem için bana yardım etmeye çalışır. }\end{array}$ & 2.2 & $\underline{40.0}$ & $\underline{28.9}$ & $\underline{20.0}$ & 6.7 & 2.2 & $\underline{1.96}$ & 1.086 \\
\hline 19 & $\begin{array}{l}\text { Okul müdürü işimi iyi yaptığımda veya iyi bir iş } \\
\text { çıardığımda beğenisini ifade eder. }\end{array}$ & 0 & 28.9 & 28.9 & 17.8 & 8.9 & 15.6 & 2.53 & 1.408 \\
\hline 20 & $\begin{array}{l}\text { Okul müdürü tüm çalışanlara kendine has } \\
\text { kişiliği olan bir birey gibi davranır. }\end{array}$ & 2.2 & 20.0 & 20.0 & $\underline{31.1}$ & $\underline{6.7}$ & $\underline{20.0}$ & $\underline{2.80}$ & 1.440 \\
\hline 21 & $\begin{array}{l}\text { Okul müdürü zamanını öğretmek ve yol } \\
\text { göstermek için harcar. }\end{array}$ & 2.2 & 28.9 & 35.6 & 15.6 & 13.3 & 4.4 & 2.22 & 1.204 \\
\hline 22 & $\begin{array}{l}\text { Okul müdürü çalışanların istek ve beklentilerinin } \\
\text { karşılanması yönünde çaba sarf eder. }\end{array}$ & 0 & 28.9 & 31.1 & 22.2 & 15.6 & 2.2 & 2.31 & 1.125 \\
\hline 23 & $\begin{array}{l}\text { Okul müdürü çalışanlara kendilerini geliştirme } \\
\text { imkânı sunar. }\end{array}$ & 2.2 & 24.4 & 22.2 & 26.7 & 17.8 & 6.7 & 2.53 & 1.290 \\
\hline
\end{tabular}

"Müdür toplantıda öğretmenlerden başarısızlığın nedenleri ve bununla ilgili alınabilecek önlemler hakkında bilgi aldı.... Genel olarak düşünceleri dinledi. Sonrasında ise 
beğendiği iki düşünceyi açıklayarak bu yönde iyileştirme yapacağını ifade etti." (Gözlemci Notu: Gözlemci B)

"Matematik öğretmenlerinden biri, güz döneminde yapılan bir toplantıda öğrencilerin önemli konuları daha iyi öğrenmesi ve derse yönelik ilgilerinin artması içinokulun duvarlarında renkli matematiksel şekillerin çizilebileceğini önerdiğini ve müdürün bunu dikkate alarak bir ay içerisinde okulun merdivenlerine matematik sembolleri, zeminine koordinat sistemi ve çarpım tablosunu çizdirdiğini söyledi...Fen bilgisi dersi için de okul duvarlarına iskelet çizilmiş. İngilizce dersi için karşıt anlamlı sıfatlar yazılmış....Okul kütüphanesi müdürün çabalarıyla oluşturulmuş ve öğrencilerin daha istekli şekilde çalışmalarını sağlayacak şekilde düzenlenmiş." (Gözlemci Notu: Gözlemci A)

Öğretmenlerin algıları dikkate alındığında, okul müdürünün dönüşümcü liderlik vasıflarından bazılarını taşımadığı sonucuna ulaşılmıştır. Verilere göre; öğretmenlerin okul müdürünün yakınında kendilerini çoğu zaman iyi hissetmedikleri ve müdürü ilham kaynağı olarak görmedikleri (\% 86.7) anlaşılmıştır. Ayrıca, öğretmenler okul müdürünün genellikle ne istediklerini keşfedemediğini ve bu nedenle isteklerini elde etmeleri için kendilerine yardımcı olamadığını (\% 88.9) söylemişlerdir. Bunlar dikkate alındığında, okul müdürünün farklı görüşleri ve yaratıcı fikirleri dikkate almasına rağmen, çoğu zaman da öğretmenlerin istediklerini tam olarak keşfedemediğinden veya anlayamadığından dolayı onların bu isteklerini gerçekleştirmelerinde genellikle yardımcı olamadığı görülmektedir.

Araştırmanın ikinci alt amac1; başarılı bir ortaokulda görev yapmakta olan okul müdürünün sürdürümcü liderlik vasıflarının neler olduğunu ortaya koymaktır. Bu amaca ilişkin sonuçlar Tablo6' de verilmiştir.

Tablo 6'ya göre, okul müdürünün en çok gösterdiği sürdürümcü liderlik davranış özellikleri, sorunlar sürekli ve önemliyse tepki göstermesi (\% 75.5), müdahale gerektiren durumlarda hataları ifade etmekte tereddüt etmemesi (\% 74.1) ve dikkatini başarısızlıklar üzerine yoğunlaştırarak başarısızlığa tepki göstermesi (\% 71.1) olarak belirlenmiştir. Bu doğrultuda, okul müdürünün okul kültüründe yapılan hatalara ve gösterilen başarısızlıklara karşı anında ve şiddetli bir tepki verdiği göze çarpmaktadır. Bunun yanında, okul müdürünün öne çıkan sürdürümcü liderlik davranışına göre olumlu özellikleri ise; hatalar üzerine odaklanması ve hataları izlemesi (\% 65.4), mevcut yöntemler işe yaradığı müddetçe performanstan hoşnut olması (\% 64.4) ve okul müdürünün işler yolunda gittiği müddetçe bir şeyleri değiştirmek için çaba göstermemesi (\% 66.6) olduğu görülmüştür. Bunun yanında, hedeflere ulaşıldığında bunu sağlayanlara memnuniyetini ifade etmesi (\% 53.3) ve inisiyatifi ele almak için çalışanları cesaretlendirmemesi (\% 64.4) sürdürümcü özelliklerinden bazıları olarak karşımıza çıkmıştır. Bu durum, okul müdürünün okul kültüründe başarıya ve sonuca odaklı bir bakış açısına hakim, başarıya veya başarısızlığa tepkisiz kalmayan ve inisiyatifi kaybetmek istemeyen bir lider rolü üstlendiğini göstermektedir.

Öğretmenlerin algıları dikkate alındığında, okul müdürünün sürdürümcü liderlik vasıflarından bazılarını taşımadığı sonucuna ulaşılmıştır. Verilere göre; okul müdürünün öğretmenlerin çabalarının karşılığında onların istediklerini elde edeceğine ilişkin güvenceyi vermediği (\% 88.9) ve başarılar elde edildiğinde ödüllerin ne olacağı konusunda açıklama yapmadığı (\% 86.7) anlaşılmıştır. Gözlem notları da okul müdürünün bu şekilde davrandığını göstermiştir.

“Öğretmenlerin bir kısmı başarı elde edilen sınıflar ya da öğrenciler için müdürün kendilerine teşekkür etmediğini; ancak başarısızlık olduğunda bu duruma tepki gösterdiğini ifade ettiler. ...Okul müdürünün yapılan hatalara odaklandığını ve bu durumdan rahatsız olduklarını söylediler.” (Gözlemci Notu: Gözlemci B) 
Tablo6. Öğretmenlerin Görüşlerine Göre Okul Müdürünün Sürdürümcü Lider Davranışlarını

Algılamalarına Yönelik Bulgular

\begin{tabular}{|c|c|c|c|c|c|c|c|c|c|}
\hline & B. Sürdürümcü Liderlik & $\frac{\text { bos }}{\mathrm{c}}$ & $\frac{1}{\%}$ & $\frac{2}{\%}$ & $\frac{\mathbf{3}}{\mathbf{c}}$ & $\frac{4}{\%}$ & $\frac{5}{\%}$ & $\overline{\boldsymbol{X}}$ & $\mathbf{s}$ \\
\hline 1 & $\begin{array}{l}\text { Okul müdürü çabalarımın karşıllı̆ı̆ında } \\
\text { istediklerimi elde edeceğime dair bana güvence } \\
\text { verir. }\end{array}$ & 0 & 40.0 & 22.2 & 22.2 & 11.1 & 4.4 & 2.18 & 1.211 \\
\hline 2 & $\begin{array}{l}\text { Okul müdürü basarılar elde edildiğinde ödüllerin } \\
\text { ne olacağı konusunda açıklama yapar. }\end{array}$ & 0 & $\underline{33.3}$ & $\underline{37.8}$ & $\underline{17.8}$ & 6.7 & 4.4 & $\underline{2.11}$ & 1.092 \\
\hline 3 & $\begin{array}{l}\text { Okulun başarısına katkı yapma konusunda } \\
\text { benden ne beklendiği ve bunun neticesinde ne } \\
\text { alacağımla ilgili olarak okul müdürü ile görüş } \\
\text { birliği söz konusudur. }\end{array}$ & 0 & 28.9 & 28.9 & 31.1 & 8.9 & 2.2 & 2.27 & 1.053 \\
\hline 4 & $\begin{array}{l}\text { Okul müdürü performans hedeflerini } \\
\text { başarmaktan kimin } \\
\text { belirtir. }\end{array}$ & 0 & 20.0 & 44.4 & 11.1 & 17.8 & 6.7 & 2.47 & 1.198 \\
\hline 5 & $\begin{array}{l}\text { Okul müdürü hedeflere ulaşıldığında bunu } \\
\text { sağlayanlara memnuniyetini ifade eder. }\end{array}$ & 0 & 11.1 & 35.6 & $\underline{20.0}$ & $\underline{13.3}$ & $\underline{20.0}$ & $\underline{2.96}$ & 1.331 \\
\hline 6 & $\begin{array}{l}\text { Okul müdürü bana sadece işimi yapmam için } \\
\text { neyi bilmem gerektiğini söyler. }\end{array}$ & 0 & 28.9 & 26.7 & 33.3 & 4.4 & 6.7 & 2.33 & 1.148 \\
\hline 7 & $\begin{array}{l}\text { Okul müdürü işler yolunda gittiği müddetçe bir } \\
\text { şeyleri değiştirmek için çaba göstermez. }\end{array}$ & 0 & 17.8 & 15.6 & $\underline{22.2}$ & $\underline{20.0}$ & $\underline{24.4}$ & $\underline{3.18}$ & 1.435 \\
\hline 8 & $\begin{array}{l}\text { Okul müdürü mevcut yöntemler ise yaradığı } \\
\text { müddetçe performanstan hoşnuttur. }\end{array}$ & 0 & 2.2 & 33.3 & $\underline{17.8}$ & $\underline{22.2}$ & $\underline{24.4}$ & $\underline{3.33}$ & 1.243 \\
\hline 9 & $\begin{array}{l}\text { Okul müdürü inisiyatifi ele almak için çalışanları } \\
\text { cesaretlendirmez. }\end{array}$ & 0 & 17.8 & 20.0 & $\underline{31.1}$ & $\underline{13.3}$ & $\underline{17.8}$ & $\underline{2.93}$ & 1.338 \\
\hline 10 & $\begin{array}{l}\text { Okul müdürü hatalar üzerine odaklanır ve } \\
\text { hataları izler. }\end{array}$ & 2.2 & 13.3 & 20.0 & $\underline{13.3}$ & $\underline{28.9}$ & $\underline{22.2}$ & $\underline{3.20}$ & 1.455 \\
\hline 11 & $\begin{array}{l}\text { Okul müdürü müdahale gerektiren durumlarda } \\
\text { hataları ifade etmekte tereddüt etmez. }\end{array}$ & 0 & 4.4 & 22.2 & $\underline{17.8}$ & $\underline{28.9}$ & $\underline{26.7}$ & $\underline{3.51}$ & 1.236 \\
\hline 12 & $\begin{array}{l}\text { Okul müdürü dikkatini başarısızlıklar üzerine } \\
\text { yoğunlaştırır ve başarısızlığa tepki gösterir. }\end{array}$ & 0 & 15.6 & 13.3 & $\underline{20.0}$ & $\underline{22.2}$ & $\underline{28.9}$ & $\underline{3.36}$ & 1.433 \\
\hline 13 & $\begin{array}{l}\text { Okul müdürü sorunlar sürekli ve önemliyse tepki } \\
\text { gösterir. }\end{array}$ & 0 & 13.3 & 11.1 & $\underline{28.9}$ & $\underline{24.4}$ & $\underline{22.2}$ & $\underline{3.31}$ & 1.311 \\
\hline 14 & Okul müdürü anlaşmazlıkları giderir. & 2.2 & 28.9 & 24.4 & 31.1 & 11.1 & 2.2 & 2.32 & 1.095 \\
\hline
\end{tabular}

$\mathrm{Bu}$ durum, okul müdürünün ödül ve ceza sistemini dikkate almasının yanında, öğretmenlerin motivasyonlarını daha yüksek tutabilecek başarı öncesi ödül açıklama anlayışını taşımadığını göstermektedir. Genel olarak ise, okul müdürünün sürdürümcü lider davranışlarını okul kültüründeki lider davranışlarında dönüşümcü liderliğe nazaran daha çok yansıttığı belirlenmiştir. Okul kültüründeki liderlik davranışlarını sadece dönüşümcü liderlik davranışlarının şekillendirmediği hem dönüşümcü hem de sürdürümcü liderlik özelliklerini taşıdığı söylenebilir.

Araştırmanın üçüncü alt amacı başarılı bir görev yapmakta olan okul müdürünün tam serbestlik tanıyan liderlik vasıflarının neler olduğunu ortaya koymaktır. Bu amaca ilişkin sonuçlar Tablo 7'de verilmiştir. 
Tablo7. Öğretmenlerin Görüşlerine Göre Okul Müdürünün Tam Serbestlik Tanıyan Lider Davranışlarını Algılamalarına Yönelik Bulgular

\begin{tabular}{|c|c|c|c|c|c|c|c|c|c|}
\hline & C. Tam Serbestlik Tanıyan Liderlik & $\frac{\text { bos }}{\mathrm{c}}$ & $\frac{1}{\%}$ & $\underline{\underline{2}}$ & $\underline{\mathbf{3}}$ & $\frac{4}{\mathrm{c}}$ & $\underline{\mathbf{5}}$ & $\bar{X}$ & $\mathbf{S}$ \\
\hline 1 & $\begin{array}{l}\text { Okul müdürü yetkili olduğunu göstermekten } \\
\text { kaçınır. }\end{array}$ & 4.4 & 35.6 & 13.3 & 22.2 & 8.9 & 15.6 & 2.48 & 1.517 \\
\hline 2 & $\begin{array}{l}\text { Okul müdürü ihtiyaç duyulduğunda ortada } \\
\text { yoktur. }\end{array}$ & 4.4 & 17.8 & 13.3 & $\underline{31.1}$ & $\underline{8.9}$ & $\underline{24.4}$ & $\underline{3.02}$ & 1.486 \\
\hline 3 & Okul müdürü karar vermekten kaçınır. & 8.9 & 13.3 & 22.2 & 26.7 & 11.1 & 17.8 & 2.77 & 1.492 \\
\hline 4 & $\begin{array}{l}\text { Okul müdürü acil sorulara cevap vermeyi } \\
\text { geciktirir. }\end{array}$ & 4.4 & 15.6 & 24.4 & $\underline{26.7}$ & $\underline{8.9}$ & $\underline{20.0}$ & $\underline{2.86}$ & 1.424 \\
\hline 5 & $\begin{array}{l}\text { Çalışanların yapmak istedikleri her şey okul } \\
\text { müdürü tarafindan kabul görür. }\end{array}$ & 8.9 & 24.4 & 20.0 & 31.1 & 15.6 & 0 & 2.25 & 1.203 \\
\hline 6 & $\begin{array}{l}\text { Okul müdürü her zaman aynı şekilde işimi } \\
\text { yapmaya devam etmemden hoşnuttur. }\end{array}$ & 11.1 & 8.9 & 17.8 & $\underline{26.7}$ & $\underline{26.7}$ & $\underline{8.9}$ & $\underline{2.82}$ & 1.419 \\
\hline 7 & $\begin{array}{l}\text { Okul müdürü işin yapılması için gerekli olanın } \\
\text { dışında benden fazla bir şey istemez. }\end{array}$ & 6.7 & 4.4 & 13.3 & $\underline{28.9}$ & $\underline{35.6}$ & $\underline{11.1}$ & $\underline{3.23}$ & 1.236 \\
\hline 8 & $\begin{array}{l}\text { Okul müdürü önemli durumlar ortaya çıktığında } \\
\text { müdahale etmekten kaçınır. }\end{array}$ & 4.4 & 15.6 & 22.2 & $\underline{26.7}$ & $\underline{11.1}$ & $\underline{20.0}$ & $\underline{2.91}$ & 1.428 \\
\hline
\end{tabular}

Tablo 7'ye göre, tam serbestlik tanıyan liderlik davranış özellikleri incelendiğinde okul müdürünün ön plana çıkan davranışları, işin yapılması için gerekli olanın dışında öğretmenden fazla bir şey istememesi (\% 75.6), ihtiyaç duyulduğunda ortada olmaması(\% 64.4) ve öğretmenlerin her zaman aynı şekilde işlerini yapmaya devam etmelerinden hoşnut olması (\% 62.3) olarak belirlenmiştir. Gözlem notuna bakıldığında da okul müdürünün öğrencilerin başarılı olmalarını beklediği; bunun dışında öğretmenlerin ders içindeki davranışlarına müdahale etmediği görülmüştür.

“Okulun İngilizce öğretmenlerinden biri müdürün kendisinin ders içindeki davranışları üzerinde baskı ortamı yaratmadığını; fakat onlardan sadece öğrencilerin sınavlarda başarılı olmalarını ve okul kültürüne uygun davranmalarını beklediğini söyledi." (Gözlem Notu: Gözlemci A)

Okul müdürünün acil sorulara cevap vermeyi geciktirdiği(\% 56.6) ve önemli durumlar ortaya çıktığında müdahale etmekten kaçındığı (\% 57.8) anlaşılmıştır. Bu durum okul müdürünün okul kültüründe bir başarısızlık veya hata yok ise öğretmenlerin işlerini aynı şekilde gerçekleştirmelerinden bir rahatsızlık duymadığını ve ihtiyaç duyulduğu anlarda ise öğretmenlerin okul müdürünün yardımından yararlanamadıklarını ortaya çıkarmıştır. Okul müdürünün bir başka tam serbestlik tanıyan özelliği ise acil sorulara cevap vermeyi geciktirmesi (\% 55.6) olarak karşımıza çıkmaktadır. Okul müdürünün okul kültüründe en yetkili ve etkin isim olduğu düşünüldüğünde alacağı kararı dikkatli olarak seçmesi gerektiği için acil soruları cevaplamayı geciktirme davranışını sergileyebileceği düşünülebilir. Okul müdürünün genel olarak okul kültüründe her liderlik stiline ilişkin davranışlar gösterdiği belirlenmiştir. Verilere göre, öne çıkan liderlik stilleri ise sürdürümcü ve tam serbestlik tanıyan liderlik olmuştur. Tam serbestlik tanıyan liderlik davranışlarının kendisini düzenleyebilen ve iyi organize olabilen örgütlerde başarıya ulaşabileceği düşünüldüğünde, ögretmenlerin de bu başarılı okul kültürünün oluşmasında büyük bir faktör olduğu ve okul kültüründe kendilerini iyi organize edebildiği düşünülebilir. Ayrıca okul müdürünün üç farklı liderlik türüne ait davranışları zamanında ve uygun durumlarda etkili olarak kullanmasının da başarılı bir okul kültürünün oluşmasında önemli bir etken olduğu düşünülmektedir. 


\section{Tartışma ve Sonuç}

Geleceğin okul yöneticilerinin taşıyacakları liderlik özellikleri, eğitimyönetimi ve dolayısıyla eğitimin kalitesi açısından büyük önem taşımaktadır.Gelecekteki okul yöneticileri, öğretmenlerle birlikte geleceğin kuşaklarını bilgi ve teknoloji toplumuna taşıyacak faktörlerin başında gelmektedir (Çelik, 2002; Demirtaş, 2005; Gümüşeli, 2001; LawandGlower, 2000). Bilgi ve teknolojik değişimlerin yarattığı etki dikkate alındığında çoğu araştırmacı (Anthony, 1994; Çelik, 1998; Lesney, 1997)tarafından dönüşümcü liderlik vasıflarına sahip okul müdürlerinin bu süreçte daha başarılı olabileceği ve sürdürümcü liderlerin bu süreçte başarısız olacağı vurgulanmaktadır. Bunun yanında ise,Fiedler (1964) liderliği sınıflamanın mümkün olmadığını ve başarılı liderlerin ise duruma göre farklı liderlik vasıflarını kullanabilen kişiler olduğunu ifade etmektedir. Yani, başarılı bir okul müdürü yeri geldiğinde dönüşümcü liderlik vasıflarını kullanabilmeli; yeri geldiğinde sürdürümcü lider olarak davranabilmeli; yeri geldiğinde ise tam serbestlik tanıyan bir lider rolü üstlenebilmelidir. Çalışmadan elde edilen sonuçlara bakıldığında da, okul müdürünün her bir liderlik rolüne (dönüşümcü, sürdürümcü ve tam serbestlik tanıyan liderlik) uygun davranışlar sergilediği görülmüştür.

Karip (1998), okul müdürlerinin var olan sorunlardan rahatsızlık duymamasının ve liderlik davranışları ve özelliklerine ilişkin yanlış algı ve güven duygusu içinde olmalarının değişimin önünde bir engel olabileceğini ifade etmektedir. Değişime yönelik okul müdürünün davranışları dikkate alındığında, araştırmanın sonuçlarına göre okul müdürü okul kültüründeki sorunların çözümünde farklı yaklaşımlar aramakta, sorunlara tepki vererek bunları ifade etmekten çekinmemekte, tüm çalışanlara kendine has kişiliği olan bir birey gibi davranarak yaratıcı ve yenilikçi düşünceye sahip ögretmenleri desteklemektedir. Bu durum, okul müdürünün okuldaki yaratıcı ve farklı yaklaşımları dikkate alan, okul kültüründe değişime açık ve farklılıklara değer veren bir lider rolü üstlendiğini göstermektedir. Buradaki okul müdürünün sorunlara tepki vermesi ve bunları ifade etmekten çekinmemesi bir sürdürümcü lider davranışı olarak karşımıza çıkmasına rağmen Karip' in (1998) ifade ettiği değişimi destekleyici ve değişimi isteyen bir tutumu gerektirmektedir. Bu da liderlik vasıflarına değişimi destekleyen okul müdürlerinin sürdürümcü lider davranışlarını da sergilediklerinin bir göstergesidir.

Bu doğrultuda araştırma sonuçlarına göre, değiş̧ime ayak uydurabilecek ve değişimi kendi içerisinde sindirerek en uygun şekilde kullanabilecek örgütlerin sürdürümcü liderlik davranışlarına ihtiyaç duyacağı düşünülmektedir Çünkü dünyadaki değişim ne kadar hızlı olursa; düzensiz ve temelini iyi oturtamamış örgütler de bundan o denli olumsuz etkileneceklerdir. Bunun yanında, değişime dirençli olmayan fakat düzen sahibi ve belli kriterlerinden ödün vermeyen disiplinli örgütler bu değişimedaha hazır olacaklardır. Bu sayede değişimi kendi temeliyle daha iyi harmanlayarak sindirebileceklerdir. $\mathrm{Bu}$ disiplini ve sürekliliği ise sürdürümcü liderlik davranışlarıyla sağlamanın daha mümkün olduğu düşünülmektedir.

Negiş Işık ve Gürsel' e (2013) göre de, okul kültüründe farklı görüşlere sahip personel ile olumlu ilişkilere sahip olmalarının, okul kültüründeki problemlerin çözümünde ortak tavır sergileyebilmelerinin ve okul yöneticisinin liderlik vasıflarına sahip olmasının okul başarısında büyük bir rolü bulunmaktadır. Bu nedenle, okul kültürünü oluşturan bu temel kişiliklerin çalışma şartlarının iyileştirilmesi, mesleğini çok daha severek yapabilecekleri iş ortamların sağlanması iyi ve etkili bir okul kültürünün oluşmasında büyük önem taşımaktadır. Bu doğrultuda, Türkiye genelinde başarılı okullarda çalışan öğretmen ve yöneticilerin okul kültürünü oluştururken yaşadıkları zorlukları veya onların sahip oldukları avantajları ortaya çıkaracak çalışmalar Türkiye'deki okul kültürünün nasıl daha iyi olabileceğine yönelik etkili ipuçları vereceği düşünülmektedir. Bu tür okullar nicel ve nitel araştırmalarla daha ayrıntılı analiz edilerek elde edilecek etkili sonuçlar, eğitim yönetimindeki ve eğitimi sistemindeki kaliteyi arttıracak önlemlerin alınmasında önemli olacaktır. 


\section{KAYNAKÇA}

ALIÇ, Mehmet. (1991). Eğitim Bilimlerinde Çă̆daş Gelişmeler. Eskişehir Anadolu Üniversitesi Yayınları.

ANTHONY, Lewin W. L. (1994).

Therelationshipbetweentransformationalandtransactionalleadershipandorganizationalculture, employeeperformance, andemployeeattrition. Doctoraldissertation, University of Miami, Florida, USA.

AYHAN, Ferda. (2006). Eğitim Örgütlerinde Öğretmenlerin İş Tatminleri ile Okul Yönetiminin Lider Davranış Biçimleri Arasındaki İlişkiler.Yüksek Lisans Tezi, Yeditepe Üniversitesi Sosyal Bilimler Enstitüsü, 2006.

BASS, Bernard M. (1985). Leadershipandperformancebeyondexpectations. New York: TheFreePress.

BASS, Bernard M. (1990). Fromtransactionaltotransformationalleadership: Learning tosharethevision. Organizational Dynamics, 8, 19-31.

BASS, Bernard M. andAVOLIOO, Bruce J. (1985).

ImprovingOrganizationalEffectivenessthroughTransformationalLeadership. Sage, Thousand Oaks, CA.

BASS, Bernard M.andAVOLIO, Bruce J. (1990). Theimplications of transactionalandtransformationalleadershipforindividual, team, andorganizationaldevelopment. In R. W. Woodman\& W. A. Pasmore (Eds.), Research in organizationalchangeanddevelopment, (4), 231-272. Greenwich, CT: JAI Press.

BASS, Bernard M. andSTEIDLMEIER, Paul (1999). Ethics, character, andauthentictransformational leadership.http://www2.stetson.edu/ bboozer/RWBStetsonSite/XMBA/ethics transf leadership .html web adresinden 06. 08. 2014 tarihinde edinilmiştir.

BURNS, James Mc Gregor. (1978). Leadership. Harper\&Row, New York.

BURSALIOĞLU, Ziya (2002). Okul Yönetiminde Yeni Yapı ve Davranıs. Pegem A Yayıncılık, On üçüncü Baskı, Ankara.

BÜYÜKÖZTÜRK, Şener.,KILIÇ ÇAKMAK, Ebru, AKGÜN, ÖzcanErkan, KARADENIZ, Şirinve DEMIREL, Funda (2013). Bilimsel Araştırma Yöntemleri. Ankara: Pegem Akademi (15. Baskı).

CEMALOĞLU, Necati (2007). Okul Yöneticilerinin Liderlik Stillerinin Farklı Değişkenler Açısından İncelenmesi. Türk Eğitim Bilimleri Dergisi, Cilt 5, Sayı 1, Kış, s. 73-112.

ÇELIK, Vehbi (1998). Eğitimde Dönüşümcü Liderlik. Kuram ve Uygulamada Eğitim Yönetimi. 4(16), Güz 1998, ss. 423-442.

ÇELIK, Vehbi (2002). Okul Kültürü ve Yönetimi. Pegem A Yayıncılık, 3. Baskı, Ankara.

DEMIRTAŞ, Hasan (2005). Etkili Sınıf Yönetimi. İçinde Kıran, H. (Ed.), Sınıf yönetiminin temelleri (ss 1-34). Ankara: Anı Yayınevi. 
DİLEK, Hakan (2005). Liderlik Tarzlarının ve Adalet Algısının; Örgütsel Bağlllık, Işs Tatmini ve Örgütsel Vatandaşlık Davranışı Üzerine Etkilerine Yönelik Bir Araştırma.Doktora Tezi, Gebze Yüksek Teknoloji Enstitüsü Sosyal Bilimler Enstitüsü.

EREN, Erol (2004). Örgütsel Davranış ve Yönetim Psikolojisi. Beta Basım Yayın, Sekizinci Bask1, İstanbul.

FİEDLER, Fred Edward (1964). A contingency model of leadershipeffectiveness. In L. Berkowitz (Ed.), Advances in experimentalsocialpsychology. New York: AcademicPress.

GÜMÜŞELİ, Ali İlker (2001). Çağdaş Okul Müdürünün Liderlik Alanları.Kuram ve Uygulamada Eğitim Yönetim Dergisi, 7 (28), Güz 2001, ss:531-348.

HANSON, Mark E. (1985). Educational Administration and Organizational Behavior. California: Allyn\& Bacon

HITT, Michael. A. andKEATS, Barbara W. (1992). Strategic leadershipandrestructuring; a reciprocalinterdependence. in Phillips, R. L.,\&Hunt, J. G. (Eds.) Strategic leadership, A multiorganizational-levelperspective. 45-61. Westport, Conn.:Quorumbooks.

HOUSE, RobertJ. andMITCHELL, TerenceR. (1974). Path-goaltheory of leadership. Contemporary Business, 3, Fall, 81-98.

KARASAR, Niyazi (2004). Bilimsel Araştırma Yöntemi. Ankara: Nobel Yayınevi.

KARIP, Emin (1998). Dönüşümcü Liderlik. Kuram ve Uygulamada Eğitim Yönetimi, 4(16), 443-465.

KILIÇ, Gülten (2006). Eğitim Kurumlarında Liderlik Tarzları ve Örgüt Kültürünün Performans Üzerindeki Etkisi.Yüksek Lisans Tezi, Erciyes Üniversitesi Sosyal Bilimler Enstitüsü.

LAW, SueandGLOVER,Derek (2000). Educational Leadershipand Learning. Buckingham: Open Uni. Press.

LESNEY, Jacqueline. J. (1977). Perceptions of transformationalleadershipbehaviors in selected successfulelementary principals. Doctoral dissertation, University of Pittsburgh, Pittsburgh, PA, USA.

LEWIN, Kurt, LIPPİT, RonaldandWHITE, RalphK. (1939). Patterns of Aggressivebehavior İn Experimentally Created Social climates. Journal of Social Psychology, 10, 271-301.

MURPHY, Joseph (1998). What'sAheadForTomorrow'sPrincipals.Principal Magazine, September. 3.

NEGIŞ̧ IŞIK, Ayşe ve GÜRSEL, Musa (2013). Başarılı Bir İlköğretim Okulunda Örgüt Kültürü: Etnografik Bir Durum Çalışması. Kuramdan Uygulamaya Eğitim Bilimleri Dergisi (KUYEB). 13(1), 201-228.

ÖZER, Selda (2009). Eğitim Örgütlerinde Lider Davranış Biçimleri İle Örgütsel Vatandaşlık Davranışı Arasındaki İlişki (Nevşehir İli Örneği). Yüksek Lisans Tezi, Erciyes Üniversitesi, Sosyal Bilimler Enstitüsü, Kayseri.

PARKMAN, Ann W. (2001). An Investigation of bass Model of Transformational and Transactional Leadership Theory in Respiratory care. Unpublished Doctoral Dissertation, University of Capella, Minneapolis, USA.

RAMEY, Jan M. (2002). The Relationship Between Leadership Styles of Nurse Managers and Staff Nurse Job Satisfacetion in Hospital Settings. Graduate Thesis, Marshall University College of Nursing and Health Professions. 
REDDIN, William (1970).Management Effectiveness.New York: McGraw- Hill.

SAKALLI, Nuray (2001). Sosyal Etkiler: Kim Kimi Nasıl Etkiler?. İmge Kitabevi, Ankara.

STUMPF, MitziNichole (2003). The Relationship of Perceived Leadership Styles of North Carolina County Extension Directors'to Job Satisfaction of County Extension Professionals. Dissertation, North Carolina State University.

ŞişMAN, Mehmet. (2004). Öğretim Liderliği. Ankara: Pegem A Yayıncılık.

VROOM, Victor H. And YETTON, Philip W. (1973). Leadership and decisionmaking. Pittsburgh, PA: University of Pittsburgh Press.

YILDIRIM, Ali ve ŞİMŞEK, Hasan (2011). Sosyal Bilimlerde Nitel Araştırma Yöntemleri (8.baskı). Ankara: Seçkin Yayınevi.

YUKL, Gary (1981). Leadership in organizations. Englewood Cliffs, New Jersey: Prentice-Hall.

ZEL, Uğur (2001). Kişilik ve Liderlik: Evrensel Boyutlarıyla Yönetsel Açıdan Araştırmalar, Teoriler ve Yorumlar. Seçkin Yayıncılık, Ankara. 